\title{
Preface
}

\section{WHY THIS BOOK?}

So much is written on institutions and economic development that a reader may wonder, why this book? This book is different because it peers inside the black box of institutions. Most of the literature treats institutions as gross abstractions, such as "rule of law," or as outcomes, such as "secure property rights." We lose sight of the host of specific norms and rules that make up societies' institutional frameworks. Thus, property rights are secure in one country and not in another because of specific constitutional clauses, laws, regulations, traditions, norms, and enforcement characteristics. Real-world institutions are complex, and this volume tries to convey this complexity without getting bogged down in a quagmire of details. It shows the forest, illustrates some of the trees, and relates both to the problem of poverty.

This book also differs in its approach to aid and development. The fundamental premise of this book is that development depends on wrenching changes in deeply-rooted institutional frameworks, changes that only happen when people transform their shared beliefs and overturn their power structures. Fundamental changes in shared beliefs and power structures do not happen because of outsiders' money, advice, pressure, or even physical force. Powerful elites oppose reforms they believe will seriously undermine their power and position in society. Non-elites fear reforms they believe will cause instability and violence. Opposition and fear cannot be overcome by more money, better advice, greater reliance on NGOs, more participation of civil society, or other oft-proposed reforms to aid. Aid provides useful humanitarian assistance, but it is ineffective in promoting development because of damaging institutions; damaging institutions that are not changed by aid. To the contrary, because aid must work within a country's power structure, aid often supports the very institutions that render it ineffective.

If aid has not worked, what has worked to change societies' beliefs and institutions? We need to know more to answer that question fully. In the last chapter of this book I suggest one force for progress - local scholars who designed new policies and advocated new paradigms that eventually transformed their economies. 


\section{WHENCE THIS BOOK?}

This book reflects my 35 years as a development practitioner and researcher, 21 at the World Bank. During those years I lived and taught economics in Bogotá, Colombia; worked as a senior economist at the Organization of American States; managed and did economic research at the World Bank; and worked intensively on 34 countries around the world. My perspective on institutions has also been shaped by reading and talking to institutionalists, especially members of the International Society for New Institutional Economics (ISNIE). Not only have I learned a great deal from talking with like-minded scholars at ISNIE, I have also learned from ISNIE's history. I co-founded ISNIE with Alexandra Benham, Lee Benham, John Drobak, Claude Ménard, and Douglass North in 1997, and in ISNIE's evolution I saw how an iconoclastic economic paradigm like new institutional economics could be nurtured and spread by scholars who could organize and communicate at low transaction costs. My perspective has also been shaped by my experience as President of the Ronald Coase Institute since its founding in 2000, working with young researchers from all over the world to promote research on the institutions that govern real economic systems. I have met almost 200 scholars from 50 different countries, participants in the institute's workshops on institutional research. The research and aspirations of these excellent researchers taught me that young scholars are a force to change the world. 